\title{
The Implementation of Community-based Disaster Risk Reduction (CBDRR) Knowledge: Case Study Landslide Vulnerable Areas in Kulon Progo District, Yogyakarta, Indonesia
}

\author{
Ikrom Mustofa, Jantsje M. Van Loon-Steensma and Robert Coates
}

\begin{abstract}
Landslide is one of several most dangerous natural hazards in Indonesia. Due to these circumstances, disaster risk reduction (DRR) programs have been implemented in many vulnerable areas to landslides. Not only the government office and disaster mitigation agency, but the local community is also actively involved in the preventive and curative efforts so called as community-based disaster risk reduction (CBDRR). This paper focused on knowing the implementation of CBDRR in Indonesia by observing the activities among local people towards CBDRR system. Kulon Progo District that is located in Yogyakarta Province, Indonesia was selected as a case to introduce the CBDRR system. This system is community-based by relying on local people capacities and capabilities with the assistance from local government, ministries and national authorities such as national disaster management agency. The study was completed by analysing and observing specific activities of CBDRR in the study case area, such as risk investigation, education and training, landslide monitoring, information analysis, early warning system and emergency response. The study is also supported with several dimensions for preparedness, such as social, economic, community capacity, institutional and infrastructure. The results show that CBDRR programs generally have increased the resilience among local people to cope with the landslides happened, although certain improvements should also be made to improve the resilience as well as to reduce the vulnerability towards the landslides and other hazards and disasters.
\end{abstract}

Keywords - Community-based, Disaster risk reduction, Emergency response, Resilience, Kulon Progo District.

\section{INTRODUCTION}

Landslides as one of the major natural disasters in Kulon Progo District has resulted in significant injury and loss to human life and damaged material and infrastructure (news.detik.com 2017, antaranews.com 2017, kompas.com 2016). In 2017, Kulon Progo was again suffered by great

Ikrom Mustofa is with the Water Systems and Global Change Group, Wageningen University and Research Centre, P.O. Box 47, 6700 AA Wageningen, The Netherlands.

Jantsje M. Van Loon-Stensma is Water Systems and Global Change Group, Wageningen University and Research Centre, P.O. Box 47, 6700 AA Wageningen, The Netherlands.

Robert Coates is with the Sociology of Development and Change, Wageningen University and Research Centre, P.O. Box 47, 6700 AA Wageningen, The Netherlands. landslides. BPBD noted that in 2017, the entire district was affected by around 629 events of landslides resulting in material losses and casualties. In fact, many areas as their housings situated are incredibly hilly that are prone to landslides, worsened by the conditions of soil types, high elevation, steeper slope, and land use and land cover. The impact of climate change also worsens those situations. The phenomenon that changes in climate variables, especially temperature, are the main factors to drive the changes in precipitation and extreme hydro-meteorological hazards such as floods and landslides.

Particular problems were revealed as the effect of landslide disasters among local people in Kulon Progo District. Some fatalities happened, but also many people were affected due to the accidents. Furthermore, landslides resulted in material losses, including housings and infrastructural damages. Other adverse situations, such as political instability and the disruption of formal education have been occurred due to disasters happened. Even, many people lost their occupation and daily activities, worsened by the massive traumas attack them that also hard to be prevented.

Those problems mentioned above are closely related to the efforts of the district toward the disaster management (Kusumasari 2014). In the experiences of the previous disaster events, there were such failed actions from the national government to manage the disaster. The slow responses from the agencies as well as the government also worsened the impact of disasters. Top-down approach and management that focus on the national government are no longer capable of solving the problem as well as to reduce the disaster risk. It is clear that there is no disaster without the occurrence of exposure and vulnerability which affect local people in such an impacted area. Hence, community involvement is seriously needed to have better management the disaster in the future. The community participation could include the preparedness before, during, and after the accident happened, so called as community-based disaster risk reduction (CBDRR).

There are many previous studies about CBDRR around the world as the way to face the potential disaster that people suffered (Raungratanaamporn 2014, Jahangiri et al. 2011, Bajek et al. 2008, Tanwattana 2018). However, the research of CBDRR in Indonesia especially in Kulon Progo has been limited. Therefore, this paper aims to understand the 
implementation of CBDRR in Kulon Progo District as well as to analyse the better CBDRR practice in the future.

\section{RESEARCH METHODOLOGY}

\section{A. Mapping}

Mapping is needed to analyse the areas in Kulon Progo that are prone to landslides. This mapping used the GIS software that combines several data and information, such as land slope, land use \& land cover, elevation, soil type, and rainfall data. The output of this mapping is the landslide hazard map.

\section{B. Semi-structured Interviews}

Interview activities were implemented as the way to collect the primary data. In this interview, snowball sampling which requires suggestion from previous persons as interviewees to choose next interviewees was capable of being applied. There was the total of 23 interviewees spread on 12 sub-district in Kulon Progo, including local people in the affected areas, local governments, and local disaster management organisations as well as volunteers in the study area.

Generally, there were specific main questions asked of interviewees during the fieldwork. Those were mostly the open-ended questions of semi-structured interviews spending between half to one hour for each person to have the conversation with them. The issues were various and the interviewees could answer as best as they can, which include the fundamental questions about exposure among local people, physical information in the study area, historical event of landslides, awareness among local community about climate change, vulnerability to the hazards, as well as their adaptive capacity to cope with disasters. Those question types could support the knowledge of CBDRR among local people. Besides the interviews, we also observed at the local people's daily activities.

\section{Secondary Data}

The secondary data were also collected in the periods of fieldwork. These data were also collected due to pursuing the better insight into the results. These consisted of the use of secondary sources of information mainly composed of: demographic data from BPS, physical and hydrological maps, rainfall and discharge data, disasters records data from regional disaster management agency (BPBD), newspapers, etc. These data were analysed together with the primary data to be explained in results and discussion.

\section{CASE STUdY}

This research was conducted in Kulon Progo District, Yogyakarta Province, Indonesia (Figure 1). Kulon Progo is the western district in the Yogyakarta Province which is located in Java island, Indonesia. This district has 12 sub-districts and 88 villages which occupy among an area of about $586 \mathrm{~km}^{2}$. These sub-districts divided into three parts of areas including Samigaluh, Kalibawang, Girimulyo, Nanggulan, Kokap,
Pengasih, Sentolo, Temon, Wates, Panjatan, Lendah and Galur. The study area extends between $7^{0} 38^{\prime} 42^{\prime \prime} \mathrm{S}$ to $7^{0} 59^{\prime} 3^{\prime \prime} \mathrm{S}$ and $110^{\circ} 11^{\prime} 37^{\prime \prime} \mathrm{E}$ to $110^{\circ} 16^{\prime} 26^{\prime \prime} \mathrm{E}$.

Kulon Progo District covered by different topography (around 0-1000 meters above sea level). The northern area is highland with the altitude between 500-1000 meters above sea level, covering several sub-districts, such as Girimulyo, Kalibawang and Samigaluh, and Kokap. These areas are designated as conservation places however they are prone to heavy landslides. In 2017, there were 416,200 people live in Kulon Progo District. Population density in this district reached 710 people $/ \mathrm{km}^{2}$ in 2017 . The agricultural sector is the primary activity among the local people living in the district.
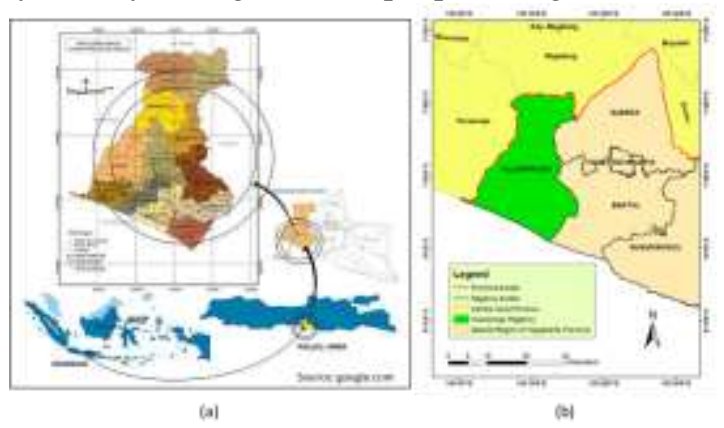

Fig 1. Map of study area in Kulon Progo District, Yogyakarta (a) source: google.com, position of Kulon Progo District (b)

\section{COMMUnity-BASEd DisASTER RISK REDUCTION (CBDRR)}

\section{A. Literature Review of CBDRR}

One important thing that needs to be explained in the capacity \& measures is the presence of community-based disaster risk reduction (CBDRR) as the approach designed to reduce the disaster risk among the local population. The origin of CBDRR is generated from the critique of the top-down, single-event relief operations of governments (Heijmans 2009). The CBDRR aims to reduce the vulnerabilities and increase the capacities among local people and communities to cope with the effect of disasters (Bollin \& Hidajat 2013). This action is significant since local people are affected by the hazard events and being the victims. Furthermore, it is such a system that brings the people's empowerment and participation towards the hazard events. As mentioned in the International Decade for Natural Disaster Reduction (IDNDR), the benefits of CBDRR are as follows:

- Enrich the experience of coping with emergencies among local people

- Enable local people to be less dependent on relief during disaster events by increasing their capacity to support their livelihoods.

- Provide appropriate education which involves the empowerment of the local people with new knowledge and leadership capability of community, as well as their ability to contribute to development initiatives

- Contribute towards the social issue of gender equity.

As the implementation of CBDRR, the role of local government is essential due to the responsibility for 
institutionalising local and community-based disaster risk management into the formal disaster management and development planning process and system (Bollin \& Hidajat 2013). However, as further explained by Heijmans (2009), the implementation of CBDRR in different areas (even country) brings different perspectives because people have different worldviews and intentions towards their actions. The homegrown CBDRR views disasters as the products of bad governance, while the mainstream CBDRR looks disasters as external calamities disrupting their social life (Bankoff \& Hillhorst, 2009). Fortunately, both CBDRR-traditions support local people to generate their capacity and resilience to disasters.

Somehow, the implementation of CBDRR in Indonesia especially in Kulon Progo District focuses on the local community efforts as main actors to developing and applying the critical policy in disaster prevention and mitigation (Kusumasari 2014). Furthermore, CBDRR involves the multisectoral and multi-level participation which not only support the government efforts in the disaster management but also considered as the actors to increase public awareness.

\section{B. The Framework of CBDRR System}

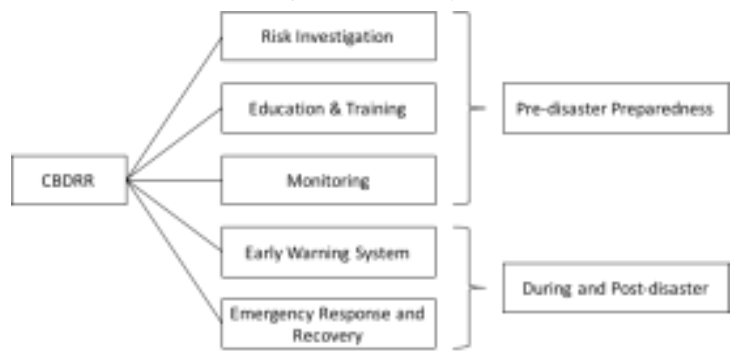

Fig 2. The conceptual framework of CBDRR system (adapted from Y. Liu et al. 2016 with the modification)

In this study, we use the conceptual framework of communitybased disaster risk reduction (CBDRR) that combine between the actions of pre-disaster preparedness and the activities during and post-disaster (Figure 2). Risk investigation, education, and monitoring could be included as the predisaster preparedness. The early warning system and emergency response are the post-disaster actions.

\section{The Participants and Stakeholders of CBDRR}

Table 1 explains stakeholder participation as well as their roles in Kulon Progo District, which are Government, Civil Society, Academia, Community Organisation, Donor Agency, and Private Sector. Each sector has their specific roles in the efforts on disaster risk management. Generally, they support other sector's role in each other. For example, while Governments have responsibility for planning and implementing the policy on disaster management, then academia sector should also support the government in research and develop tools for disaster management in such area. These also relate with other sectors that should be worked together and well-coordinated.
TABLE I. STAKEHOLDERS INVOLVEMENT AND THEIR ROLES TOWARD DISASTER RISK MANAGEMENT IN KULON PROGO DISTRICT

\begin{tabular}{|c|c|c|}
\hline Sector & Actors & Role \\
\hline Government & $\begin{array}{l}\text { BNPB, BPBD, Bappeda, } \\
\text { Legal Bureau, Financial } \\
\text { Bureau, Public Works, Social } \\
\text { Affairs, Police, Water } \\
\text { Management, Energy and } \\
\text { Mineral Energy, Inspectorate, } \\
\text { Sub-district government, } \\
\text { Village Government, } \\
\text { Educational Agency, } \\
\text { Transportation Agency, SAR, } \\
\text { Hospital management, PDAM, } \\
\text { Agricultural Agency, } \\
\text { Meteorological Agency } \\
\text { (BMKG) }\end{array}$ & $\begin{array}{l}\text { Responsible for } \\
\text { planning and } \\
\text { implementing the } \\
\text { policy on disaster } \\
\text { management, but } \\
\text { also allocating } \\
\text { enough budget and } \\
\text { other resources }\end{array}$ \\
\hline $\begin{array}{l}\text { Civil } \\
\text { society }\end{array}$ & $\begin{array}{l}\text { Red Cross, Disaster } \\
\text { Preparedness Youth } \\
\text { (Tagana), Pramuka }\end{array}$ & $\begin{array}{l}\text { Bridging the gaps } \\
\text { between } \\
\text { government and } \\
\text { local people, and } \\
\text { empowering the } \\
\text { community }\end{array}$ \\
\hline Academia & $\begin{array}{l}\text { Gadjah Mada University } \\
\text { (UGM), Yogyakarta State } \\
\text { University (UNY) }\end{array}$ & $\begin{array}{l}\text { Supporting the } \\
\text { government in } \\
\text { research and } \\
\text { developing tools for } \\
\text { disaster } \\
\text { management in } \\
\text { such area }\end{array}$ \\
\hline $\begin{array}{l}\text { Community } \\
\text { organisation }\end{array}$ & $\begin{array}{l}\text { Family empowerment program } \\
\text { (PKK), Karang Taruna, } \\
\text { Disaster Preparedness } \\
\text { Village, Disaster Resilient } \\
\text { Village, Dasa Wisma, } \\
\text { Posyandu, Religion } \\
\text { Organisation, Farmer } \\
\text { Community Organisation, } \\
\text { Diaspora and migrant workers } \\
\text { community }\end{array}$ & $\begin{array}{l}\text { Working together } \\
\text { with the } \\
\text { government in } \\
\text { developing } \\
\text { adaptation and } \\
\text { mitigation plans } \\
\text { towards the } \\
\text { disasters happened }\end{array}$ \\
\hline $\begin{array}{l}\text { Donor } \\
\text { agency }\end{array}$ & Political parties, NGO & $\begin{array}{l}\text { Supporting funding } \\
\text { and human } \\
\text { resources in } \\
\text { developing } \\
\text { regulations and } \\
\text { other rules }\end{array}$ \\
\hline $\begin{array}{l}\text { Private } \\
\text { sector }\end{array}$ & $\begin{array}{l}\text { Private banks, local and } \\
\text { multinational company }\end{array}$ & $\begin{array}{l}\text { Supporting the } \\
\text { government's role } \\
\text { and help to reduce } \\
\text { the impact of such } \\
\text { hazards in the area. }\end{array}$ \\
\hline
\end{tabular}

Note: bold font indicates that the actor is being interviewed during fieldwork

\section{RESEARCH RESULT}

\section{A. Historical Landslide Events}

Kulon Progo District has suffered landslides since many years ago. Based on the timeline figured below (Figure 3), certain years suffered great landslides. It is clear that landslides always happened almost every year, but occurred in various magnitude and probability. Significant landslide events happened every few years. Hazards with low frequency and severity (low-level hazards) usually occurred due to the 
adverse effect of previous events with higher severity and frequency (high-level hazards). Even, low-level hazards also probably caused the occurrence of high-level hazards. These could be seen to the timeline mentioning several crucial years as high-level hazards happened. Based on the timeline, the frequency of hazards become higher from year to year, especially after 2000 .

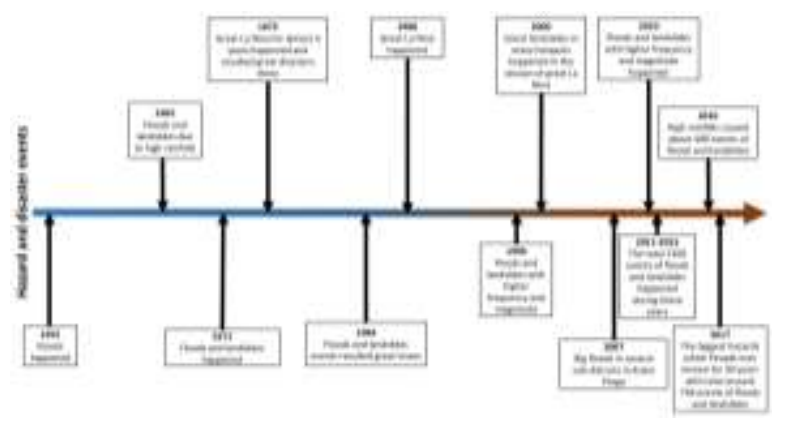

Fig 3. The timeline of flood and landslide events (this timeline is based on the information from the interviews, newspapers, and official documents)

In the periods of 2008-2017, landslide events significantly increased due to the influences of many related factors previously described (Figure 4). In 2008, around 253 landslides happened (Appendix 4). While from 2009 to 2015, the number of events in each year was still abundant but not as higher as 2008 events. Hazards severely increased in 2016 noting around 340 landslides. The total number of hazards risen again in 2017 resulting 629 landslide events.

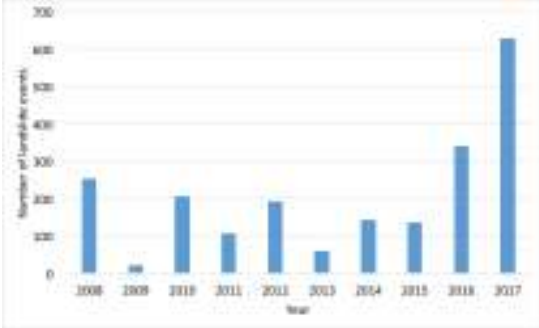

Fig 4. Total hazards per year from 2008-2017 in Kulon Progo (source: BPS)

Several sub-districts have long experiences towards the landslides such as Girimulyo, Kalibawang, Kokap, Pengasih, and Samigaluh (Figure 5). Even, Girimulyo has been affected by more less 817 total landslide events from 2008 to 2017 with various severity. Additionally, some landslides have resulted in the significant number of casualties.

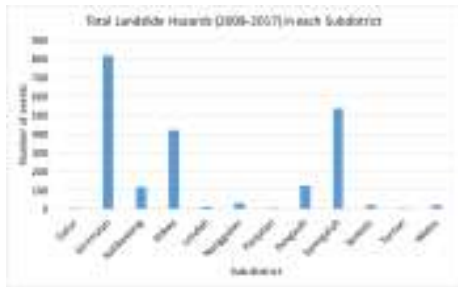

Fig 5. Total landslide hazards in the periods 2008-2017 in each Sub district (source: BPS)

\section{B. Landslide Mapping in the Area}

The landslide hazard map describes that some areas in Kulon Progo District are vulnerable to landslides because of the characteristics covering the fields. The landslide hazard map is also divided into three categories, from the low level of hazards to the high potency of landslides. Based on those categories, there are some sub-districts which are located on the high level of landslides, including Kokap, Girimulyo, Samigaluh, and Kalibawang that can be seen by the red colour areas.

Specific factors affect the occurrence of landslides. Slope angle is the first factor that has the significant impact on the instability of lands. Besides that, the elevation of the fields from sea level surface also deliver the potential hazards. The area which is located at high altitude will suffer higher exposure to the landslides. Rainfall intensity also plays the significant role due to almost all landslides happened during the heavy rainfalls. Furthermore, soil type, land use and land cover are also the important factors that give the contribution towards landslides. Additionally, people's activities such as deforestation, agricultural activities, and land use change have worsened the susceptibility of certain areas to the landslides.

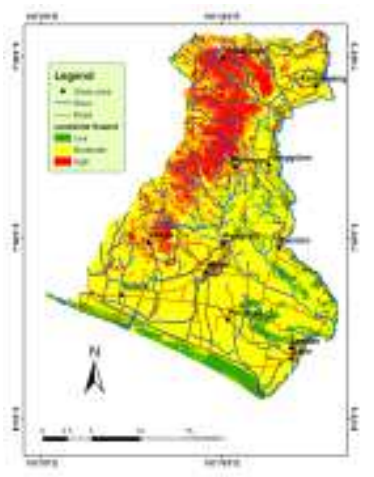

Fig 6. Landslide hazard map.

\section{Existing Practices of CBDRR in Kulon Progo}

TABLE II. CURRENT PRACTICE OF CBDRR IN KULON PROGO

\begin{tabular}{|c|c|}
\hline Indicator & Practices \\
\hline $\begin{array}{l}\text { Risk } \\
\text { investigation }\end{array}$ & $\begin{array}{l}\text { - Landslide investigation (understand triggers, } \\
\text { - Element at risk (people, property, road, etc) } \\
\text { - Escape routine, shelters } \\
\text { - Warning board } \\
\text { - Landslide risk map }\end{array}$ \\
\hline $\begin{array}{l}\text { Education \& } \\
\text { training }\end{array}$ & $\begin{array}{l}\text { - Monitoring and investigation skills } \\
\text { - Emergency response, self-rescue, first aid } \\
\text { - Appropriate agricultural, land use, safe } \\
\text { construction, water management } \\
\end{array}$ \\
\hline Monitoring & $\begin{array}{l}\text { - Community based landslide monitoring } \\
\text { - Real-time monitoring system } \\
\text { - Collaborative departments in CBDRR }\end{array}$ \\
\hline $\begin{array}{l}\text { Early warning } \\
\text { system }\end{array}$ & $\begin{array}{l}\text { - Expert investigation } \\
\text { - Deformation stage, impacted zone, alert level and } \\
\text { information release } \\
\text { - Emergency plan }\end{array}$ \\
\hline $\begin{array}{l}\text { Emergency } \\
\text { response and } \\
\text { recovery }\end{array}$ & $\begin{array}{l}\text { - Participating departments } \\
\text { - Emergency measures } \\
\text { - Development after disasters (economic, social, } \\
\text { and infrastructure) }\end{array}$ \\
\hline
\end{tabular}

\section{Risk investigation}

The risk investigation helps local people, as well as government and expert to deeply understand about landslides. It could be the factors affecting landslides, as well as the 
element at risk. In the risk analysis, it is essential to know about the hazard, exposure, vulnerability, and the capacity \& measures among local people. The risk is the resultant of those factors.

Based on the result, the current implementation of CBDRR in Kulon Progo has applied risk investigation to manage the adverse situation. Several ways to do this phase are employing a landslide hazard map and participatory map. Besides, people also conduct the forum group discussion (FGD) to categorise the risk they face together with the exposure, vulnerability, and their resilience.

Therefore, based on the discussion, local people, as well as government and private sectors, will understand which areas suffer more disaster risk, and which areas are safer than others. Adjusting the evacuation route, relief, and development is critical.

\section{Education \& training}

The disaster education and training help the community in such affected areas to face the disaster in a collective approach. The model of practice will be adjusted from the type of catastrophe in the area. Based on the result, the implementation of training in Kulon Progo District as the efforts to face landslide risks is distinguished by several activities, levels, and participants. The activities could be the simulation while the landslide happened, how people were evacuated, especially how they help people with disabilities. Besides that, the activities especially the simulation could be presented using interactive games, outdoor activities, and the discussion among local people. Sometimes, the simulation also receives the kind of local wisdom and local knowledge that residents have because it will be more effective during the disasters. Regarding the levels, the training and simulation were implemented on different levels. First, several volunteers were invited to join the training on national and district level. After that, they started to deliver the knowledge to local people in the village.

\section{Monitoring}

As the figure 7, the role of disaster management agency in each level is robust, including the coordination and communication between regional disaster management agency and national disaster management. It is also clear that each multi-level of governance has their power, even for local (village) government which not only received alert information but also inform \& request for aids as well as lobby government for improvements. Furthermore, in each level, there are several organisations and agencies which are also actively involved in managing the disasters, such as disaster preparedness village, disaster resilient village, youth organisation, social agencies, red cross, fire agencies, health agencies, etc.

\section{Early warning systems (EWS)}

During the observation, specific EWS tools have been installed near the prone areas to landslides. Local people, especially who live near the EWS tools were asked to monitor and manage the current and actual information from the devices. Besides, they also got the responsibility to repair the machines if such problems were coming from an internal tool and external aspects. Furthermore, to reach better early warning, local people also activate their activities in social media, such as Whatsapp, twitter, and the short message. Those are used to deliver the information of current disaster immediately. However, the handling of traditional tools for informing the hazard events is still alive. This EWS also put attention on the emergency plan, such as the evacuation route. People have been notified to manage who escape first and who should help others.

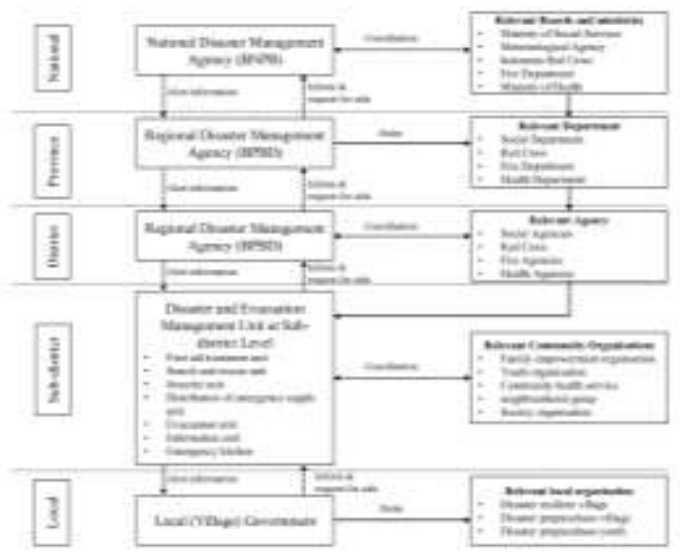

Fig 7. Community based Disaster Risk Management- network scheme (Source: ADPC 2008, Kusumasari 2014, and being modified by the supporting information from interviews)

\section{Emergency response \& recovery}

Several activities have been implemented in emergency response and recovery. It should be known that Kulon Progo District has the emergency fund that can be used during the disaster. Besides, the local resource base program also empowered the community. Furthermore, social capital such as working together between neighbours also played the significant role in the response and recovery.

\section{D.The Assessment of CBDRR Implementation}

TABLE III. THE ASSESSMENT OF CBDRR IMPLEMENTATION

\begin{tabular}{|l|l|l|}
\hline Indicator of CBDRR & $\begin{array}{l}\text { Before the } \\
\text { Implementation } \\
\text { of CBDRR }\end{array}$ & $\begin{array}{l}\text { After the } \\
\text { Implementation of } \\
\text { CBDRR }\end{array}$ \\
\hline $\begin{array}{l}\text { Risk investigation } \\
\text { (focused to landslide } \\
\text { investigation) }\end{array}$ & Moderate & High \\
\hline $\begin{array}{l}\text { Education and training } \\
\text { (especially for emergency } \\
\text { response training and self- } \\
\text { rescue during disasters) }\end{array}$ & Low & High \\
\hline $\begin{array}{l}\text { Monitoring (including the } \\
\text { collaborative departments) }\end{array}$ & Low & Moderate \\
\hline $\begin{array}{l}\text { Early warning system } \\
\text { (warn information) }\end{array}$ & Low & High \\
\hline $\begin{array}{l}\text { Emergency response and } \\
\text { recovery (post-disaster } \\
\text { response and emergency } \\
\text { exploration) }\end{array}$ & Moderate & High \\
\hline
\end{tabular}

Note: The categorizations were obtained from interview analysis supported by secondary data. Low: less discussion about the indicator as well as the implementation

Moderate: have been available, but not well-implemented

High: Have been implemented well, just need some improvements 
There are several differences between the circumstances before and after the implementation of CBDRR in Kulon Progo District. Based on the result that combines several inputs from interviews and secondary data, the categorisations from several indicators were obtained. Before the implementation of CBDRR in Kulon Progo District, the disaster management was inferior. It could be seen from the level of each index that is situated on the low level of categorisation. There were less discussion and also community involvement about the disasters especially in several aspects, such as education and training, collaborative departments, and early warning system. Some reasons for the situations are the low community involvement in the disaster management, lack of knowledge at the community level, and the different perspective among multi-levels and multi-actors.

The condition was getting better after the implementation of CBDRR in Kulon Progo District. Due to the increase in community involvement, followed by the improvement of knowledge among local people, the categorisation has been increased simultaneously. It could be seen from several aspects that contain the substantial rate of implementation, especially from the risk investigation, education and training, early warning system, and the emergency response and recovery.

\section{DISCUSSION AND CONCLUSION}

CBDRR activities are also closely linked to the efforts to preserve the value of local wisdom at the community level. For example, gotong-royong (working together among local people/ mutual aim) which is a joint activity between neighbours as their social capital by conducting the collective efforts and sharing responsibility for public needs or celebration within their society (Dokhi et al. 2017). Local people in Kulon Progo routinely do the actions, such as cleaning roads and irrigation canals and planting trees together. These activities were also done by them when disaster strikes. With their volunteerism and togetherness, they together cleaned up the former ground and debris both from the floods and landslides. These community-based empowerment activities also gave the contribution to numerous disaster volunteers from various organisations. The task of these volunteers was to help disaster victims during the disaster until after the accident. They made public kitchens, provided food, cleaned up houses buried in landslides or floods, and also collected donations and physical aids from various parties.

However, several issues need to be discussed. Previous research and this study proved that the observation about CBDRR needs a long time not only to interview local people but also observe them as well as their change. In this study, the fieldwork was very limited. Hence, the information obtained was insufficient. Furthermore, the fieldwork needed more people to be interviewed. People often have the different perspectives to face the situation.

Finally, regarding the observation and study, CBDRR has improved the successful disaster management in Kulon Progo District. It is clear that the primary objectives of CBDRR in Kulon Progo are to increase the awareness among local people as well as to improve their capacity and capability by enhancing the education and training. But also to enhance the roles of local people towards the lobbying the government regarding the disasters.

\section{REFERENCES}

[1] Asian Disaster Preparedness Center, Monitoring and Reporting Progress on Community-Based Disaster Risk Management in Indonesia. Jakarta, Indonesia: European Commision Humanitarian Aid, UNESCAP, ADPC, 2008.

[2] R. Bajek, B. Matsuda, and N. Okada, "Japan's Jishu-bosai-soshiki community activities: analysis of its role in participatory community disaster risk management," Natural Hazards, vol. 44(2), pp. 281-292, 2008. https://doi.org/10.1007/s11069-007-9107-4

[3] G. Bankoff, and D. Hilhorst, "The politics of risk in the Philippines: comparing state and NGO perceptions of disaster management," Disasters, vol. 33(4), pp. 686-704, 2009. https://doi.org/10.1111/j.1467-7717.2009.01104.x

[4] C. Bollin, and R. Hidajat, "Community-based risk index: pilot implementation in Indonesia," In Measuring Vulnerability to Natural Hazards: Towards Disaster Resilient Societies, J. Birkmann, New York, NY: United Nations University Press, 2013.

[5] M. Dokhi, T. H. Siagian, A. P. Utomo, and E. Rumanitha, "Social Capital and Disaster Preparedness in Indonesia: A Quantitative Assessment Through Binary Logistic Regression," In Disaster Risk Reduction in Indonesia. Springer, Cham, pp. 589-608, 2017. https://doi.org/10.1007/978-3-319-54466-3_24

[6] A. Heijmans, The social life of community-based disaster risk management: Origins, politics and framing policies. Working paper, 2009, No. 20.

[7] IPCC, Managing the Risks of Extreme Events and Disasters to Advance Climate Change Adaptation. A Special Report of Working Groups I and II of the Intergovernmental Panel on Climate Change [Field, C.B., V. Barros, T.F. Stocker, D. Qin, D.J. Dokken, K.L. Ebi, M.D. Mastrandrea, K.J. Mach, G.-K. Plattner, S.K. Allen, M. Tignor, and P.M. Midgley (eds.)]. Cambridge University Press, Cambridge, UK, and New York, NY, USA, 582 pp, 2012.

[8] K. Jahangiri, Y. O. Izadkhah, and S. J. Tabibi, "A comparative study on community-based disaster management in selected countries and designing a model for Iran," Disaster Prevention and Management: An International Journal, vol. 20(1), pp. 82-94, 2011. https://doi.org/10.1108/09653561111111108

[9] B. Kusumasari, Disaster management and local government capacity. Yogyakarta: Gava Media, 2014.

[10] Y. Liu, K. Yin, L. Chen, W. Wang, and Y. Liu, "A community-based disaster risk reduction system in Wanzhou, China," International Journal of Disaster Risk Reduction, vol. 19, pp. 379-389, 2016. https://doi.org/10.1016/j.ijdrr.2016.09.009

[11] I. S. Raungratanaamporn, "Determination Towards Decision of Public Response in Flood Situation: Case Study in Urban Flood Prone Area in Central Region in Thailand," Applied Environmental Research, vol. 36(3), pp. 77-94, 2014.

[12] P. Tanwattana, "Systematizing Community-Based Disaster Risk Management (CBDRM): Case of urban flood-prone community in Thailand upstream area," International Journal of Disaster Risk Reduction, vol. 28, pp. 798-812, 2018. https://doi.org/10.1016/j.ijdrr.2018.02.010

[13] R. Hanafi, (2017, November 29). Banjir melanda Kulon Progo, ratusan warga mengungsi. Detik News, p. 1. Retrieved from https://news.detik.com.

[14] Sutarmi (2017, November 28). Banjir dan longsor landa Kulon Progo. Antara News, p.1. Retrieved from https://www.antaranews.com.

[15] T. Wahono, (2016, June 19). Banjir dan longsor juga melanda Kulon Progo. Kompas Regional, p. 1. Retrieved from https://regional.kompas.com. 